\title{
Article \\ Hybrid Triploid Induced by Megaspore Chromosome Doubling in Jujube (Ziziphus jujuba Mill.) 'Maya' and Its Characteristics
}

\author{
Songshan Liu, Chenxing Zhang, Weicong Yang, Xiang Li, Lu Hou, Meng Li, Xiaoming Pang and Yingyue Li * \\ National Engineering Laboratory for Tree Breeding, College of Biological Sciences and Technology, \\ Beijing Forestry University, Beijing 100083, China; songshanliu@bjfu.edu.cn (S.L.); \\ chenxingzhang@bjfu.edu.cn (C.Z.); 19948657165@163.com (W.Y.); lx2016bjfu@163.com (X.L.); \\ houlu822@163.com (L.H.); limeng@bjfu.edu.cn (M.L.); xmpang@bjfu.edu.cn (X.P.) \\ * Correspondence: yingyueli@bjfu.edu.cn
}

Citation: Liu, S.; Zhang, C.; Yang, W.; Li, X.; Hou, L.; Li, M.; Pang, X.; Li, Y. Hybrid Triploid Induced by Megaspore Chromosome Doubling in Jujube (Ziziphus jujuba Mill.) 'Maya' and Its Characteristics. Forests 2021, 12, 112. https://doi.org/10.3390/ f12020112

Received: 28 December 2020

Accepted: 19 January 2021

Published: 20 January 2021

Publisher's Note: MDPI stays neutral with regard to jurisdictional claims in published maps and institutional affiliations.

Copyright: (c) 2021 by the authors. Licensee MDPI, Basel, Switzerland. This article is an open access article distributed under the terms and conditions of the Creative Commons Attribution (CC BY) license (https:// creativecommons.org/licenses/by/ $4.0 /)$.
Abstract: Polyploid breeding is an important strategy for tree improvement because polyploid individuals typically show superior traits, such as improved growth, stress resistance, and superior fruit quality. Artificial induction of chromosome doubling of female gametes is an effective approach to obtain triploid progeny. However, no triploid fruit tree cultivars have been developed using this approach. The objective of this study was to explore the utility of chromosome doubling in female gametes of 'Maya' jujube to produce triploid individuals. The temporal relationship between flower bud morphology and the megaspore meiotic stage was studied to guide the optimal timing of colchicine treatment. Colchicine solution was applied to bearing shoots of mature 'Maya' jujube trees in a field experiment using two treatment methods (improved cotton leaching and injection method) and three concentrations $(0.3 \%, 0.4 \%$, and $0.5 \%)$. The water transport rate of 'Maya' jujube shoots was studied using dye solution to judge the effectiveness and timing of the colchicine treatment methods. Two triploids were identified among the progenies from the colchicine-treated shoots. The highest efficiency of triploid production was 3.3\% when flower buds of diameter 1.76-2.12 mm were treated with $0.3 \%$ colchicine solution for $4 \mathrm{~h}$ using an improved cotton leaching method. The ground diameter, plant thorn length, leaf width, leaf area, stomatal length, stomatal width, chlorophyll content, and photosynthetic parameters of one triploid individual were significantly higher than those of diploids of identical parentage at 18 months old. Thus, induction of $2 n$ megaspores is an effective approach to generate triploid jujube. These results are expected to promote and accelerate triploid breeding in fruit trees.

Keywords: 'Maya' jujube; $2 n$ female gamete; triploid

\section{Introduction}

Polyploid breeding is an important strategy for fruit tree improvement. Polyploid fruit trees typically show excellent performance in stress resistance, growth, and fruit size, as well as texture, for example [1-3]. Such traits may significantly shorten the breeding period, and improve the adaptability and competitiveness of fruit trees. Consequently, polyploids have been widely used in fruit tree production [4-6]. The use of colchicine $[7,8]$ or high temperature $[9,10]$ to induce the formation of $2 n$ gametes and their use in controlled pollinations is an important approach to obtain triploid progeny [11]. As a polyploidization agent, colchicine treatment is the most common and effective method applied to produce diploid gametes and triploids, as has been reported for poplar [12], cassava [13], Eucalyptus [14], and Cymbidium [15]. The triploids generated by this method enable simultaneous utilization of heterosis and gene dosage effects to obtain new cultivars with superior traits $[16,17]$. During fertilization, the induced $2 n$ pollen usually exhibits weaker development and competitiveness compared with haploid pollen [18], whereas $2 n$ female gametes show greater efficiency for formation of triploids by hybridization [19]. Induction of $2 n$ female gametes by chromosome doubling in the megaspore or embryo sac has been 
successfully used to obtain triploid plants in poplar [20], mulberry [21], Eucalyptus [8], Eucommia [9]. However, few studies have investigated artificial induction of unreduced gametes to induce polyploidy in fruit trees. To date, no triploid fruit tree cultivar has been developed by this approach.

Chinese jujube (Ziziphus jujube Mill.) belongs to the family Rhamnaceae. It is an economically important woody fruit tree that originated in China and has a long cultivation history of more than 7000 years [22]. Jujube fruit are rich in vitamin C, sugar, iron, calcium, zinc, and other nutrients, and have medicinal properties [23,24]. Of the cultivated selections, 'Maya' jujube is among the most favored cultivars. The fruit of 'Maya' jujube has an attractive oval shape, thin peel, and is rich in nutrients and, thus, is popular among consumers. The fruit matures from late August to early September. Compared with other cultivars, the fruit is early maturing, which enables earlier marketing and is economically beneficial. The cultivar, thus, has strong potential for market development [25]. However, the fruit of 'Maya' jujube is smaller in size [26] and is more prone to cracking during the white maturity stage [27] than the fruit of many other commercial jujube cultivars. Therefore, both an increase in fruit size and resistance to fruit cracking are important goals for 'Maya' jujube breeding.

The objective of this study was to explore the utility of chromosome doubling in female gametes of 'Maya' jujube to produce triploids. Morphological and cytological observations of flower buds were conducted to determine the appropriate concentration and method of colchicine treatment for induction of chromosome doubling in the megaspore. Assessment of the phenotypic traits of the triploids raised provided a theoretical basis for practical application of this germplasm. The results provide a foundation for chromosome doubling in female gametes and the potential utility of triploid germplasm in the breeding of fruit trees.

\section{Materials and Methods}

\subsection{Plant Materials}

This study was performed with the 6-year-old robust trees of 'Maya' jujube $(2 n=2 x=24)$, located at the Qiyuan village, Liucun Town, Changping District, Beijing in China. These jujube trees were grafted onto the two-year-old sour jujube rootstock six years ago.

\subsection{Morphological and Cytological Observations of Flower Buds}

The external morphology of the flower buds on the robust secondary shoots were observed every three days from April to June in 2017. Flower buds diameter were measured with vernier caliper and sampled every three days. At least 30 samples were measured each time and repeated three times. All flower buds collected from bearing shoots fixed in FAA fixative (70\% ethanol/acetic acid $/ 40 \%$ formaldehyde, $90: 5: 5)$ at $4{ }^{\circ} \mathrm{C}$ for $24 \mathrm{~h}$. Ovaries from each fixed bud were embedded in paraffin and sectioned every 8-10 $\mu \mathrm{m}$ and stained with iron hematoxylin for megasporogenesis observation under an Olympus BX51 (BX51,Olympus, Tokyo, Japan)microscope.

\subsection{Water Transport of 'Maya' Jujube Shoots}

The ability of the 'Maya' jujube shoots to conduct water was evaluated using dye tracer method [28]. A total of 24 semi-lignified shoots, 24 lignified shoots, and six bearing shoots were randomly selected. According to the cotton leaching method of Xi et al. [12], basic fuchsin $0.1 \%$ aqueous was introduced from the base of the selected shoots. The experiment was carried out in the morning on a sunny day in May 2018. The treated shoots were observed every $30 \mathrm{~min}$ and the experiment was lasted for $4 \mathrm{~h}$.

\subsection{Colchicine Treatment in Field}

Bearing shoots were selected based on the determination of the developmental process of the megasporogenesis, were treated with $0.3 \%, 0.4 \%$, and $0.5 \%$ colchicine solution for $4 \mathrm{~h}$ in May 2018 (Table 1). Colchicine treatments were performed by injection [29] and 
improved cotton leaching methods, which was improved from Xi et al. [12] by cutting holes that can deep in the xylem on the base of secondary shoot and wrapping cotton soaked with colchicine solution on the holes. The holes are about 30-40 cm away from the flower buds At least six secondary shoots were treated per treatment and replicated five times. Another 30 untreated shoots served as the control group. The jujube fruits were collected after the trees were naturally pollinated and the fruits were mature.

Table 1. The treatment of colchicine concentration and application method.

\begin{tabular}{ccc}
\hline Treatment Number & Colchicine Concentration (\%) & Treatment Method \\
\hline 1 & 0.3 & injection \\
2 & 0.4 & injection \\
3 & 0.5 & injection \\
4 & 0.3 & improved cotton leaching \\
5 & 0.4 & improved cotton leaching \\
6 & 0.5 & improved cotton leaching \\
\hline
\end{tabular}

\subsection{Ploidy Determination and Paternal Analysis}

Seeds from the treated mature fruits were collected and germinated in December. When the seedlings grew to approximately $15 \mathrm{~cm}$ with 6-8 leaves, collected 1-2 fresh leaves for further ploidy level detection. The samples were treated according to the methods from Cui et al. [30] and flow cytometry (Beckman Coulter, CA, USA) was used to detect the ploidy level of offspring.

Leaves of the maternal 'Maya' jujube trees, the offspring and all the possible paternal jujube trees around the orchard were collected and stored at $-80^{\circ} \mathrm{C}$. DNA was extracted according to the instructions of the kit (Tiangen Biochemical Technology Co., LTD., Beijing, China) and uniformly diluted to $20 \mathrm{ng} / \mu \mathrm{L}$ and put into the refrigerator at $-20^{\circ} \mathrm{C}$ for later use. The exact male parent for every offspring was identified with highly polymorphic and reproducible primers from the SSR primers previously developed in our laboratory (Table 2). The reaction procedure was referred to Liang et al. [31]. Cervus 3.0 software was used to analyze the parent based on the maximum likelihood method.

Table 2. SSR primer information table.

\begin{tabular}{|c|c|c|c|c|}
\hline Name & $\begin{array}{l}\text { Repeat } \\
\text { Motifs }\end{array}$ & Forward Primer $\left(5^{\prime}-3^{\prime}\right)$ & Reverse Primer $\left(3^{\prime}-5^{\prime}\right)$ & $\begin{array}{c}\text { Expected } \\
\text { Length (bp) }\end{array}$ \\
\hline BFU0308 & $(\mathrm{TC}) 11$ & TTТССАССССААААТАССАА & AGACGCTGGATGAGGATGAT & 176 \\
\hline BFU0574 & $(\mathrm{CA}) 7$ & GAAGGTTGAAGATGCTCTCTCTC & CCTGACATCCATTTGAAGGAA & 114 \\
\hline BFU0546 & $(\mathrm{CT}) 8$ & CGTGACAGCACAATGTTTGA & AAACCATGAAATATCCAAGCAA & 156 \\
\hline BFU0277 & (GA)11 & GCACTACCCTGTGGAACTCAA & AGTGTTGACCTGGCAAGAAGA & 236 \\
\hline BFU1205 & $(\mathrm{CA}) 8$ & TGTTGCTGGTTCAATTCCAG & CTTATGGCTTTTTCATTTTGTGA & 151 \\
\hline BFU0377 & (CT)10 & CCAGCTGGTATCCAATTGCT & ACGACGATGCCATGAAAGAT & 283 \\
\hline BFU0467 & (TC)9 & CCGGACCGAGTGGAGTTATTA & AGAATATGGCATCAACCTATACCA & 222 \\
\hline BFU1157 & (GA)9 & TCССТАААТТАСССТТСССААТ & AAAGCGACAGCGAAAACTGT & 234 \\
\hline
\end{tabular}

\subsection{Phenotypic Trait Measurement of Triploid and Diploid Offspring}

The offspring cultivated for 14 months were transplanted to the Beijing Forestry University Chinese Jujube Breeding Experimental Station (Cangzhou County, Hebei province, China) and adopt the same management measures. The diploid grew well while only one triploid survived. The abaxial epidermis were isolated from the middle part of the mature leaves of each offspring and mounted on slides for microscopic observations. The length, width, and density of 30 stomata per leaf were measured randomly using ImageJ software (version 1.51, NIH, Bethesda, MD, USA).

The phenotypic traits of triploid (TM) and diploid progeny plants (DM-6-14, DM-7-4, and DM-7-5) of the same parent were measured in July 2020. Plant height was measured 
using a flexible rule. Ground stem and thorn length were measured with a Vernier caliper. Mature leaves from the top shoot of each plant were used to measure their photosynthetic parameters at 9-11 o'clock on a sunny day in August (Li-Cor Inc., Lincoln, NE, USA). The length, width, and area of leaf were measured by ImageJ software (version 1.51, $\mathrm{NIH}$, Bethesda, MD, USA). The chlorophyll content was measured with a CCM-200 Plus chlorophyll content meter (OPTI-sciences Inc., Hudson, NH, USA).

\subsection{Statistical Analysis}

SPSS software (version 19.0, SPSS Inc., Chicago, IL, USA) was used to conduct one-way ANOVA and Duncan multiple comparisons to determine whether there were differences among the data.

\section{Results}

\subsection{Development of the Flower Bud and Gametophytes of 'Maya' Jujube}

The flower development of 'Maya' jujube was monitored. In the Changping area of Beijing in China, the mother-bearing shoots sprouted on 13 April, from which the bearing shoots grew, and the leaves unfolded. Flower buds developed on bearing shoots in early May, blooming was initiated in mid-May, and peak blooming occurred in early June. During the reproductive phase, flowering and fruiting overlapped. An individual flower passed through seven phenological stages: bud split (Figure 1a), initial opening (Figure 1b), sepal flattening (Figure 1c), petal flattening (Figure 1d), stamen flattening (Figure 1e), stamen withering (Figure 1f), and ovary swelling (Figure 1g).
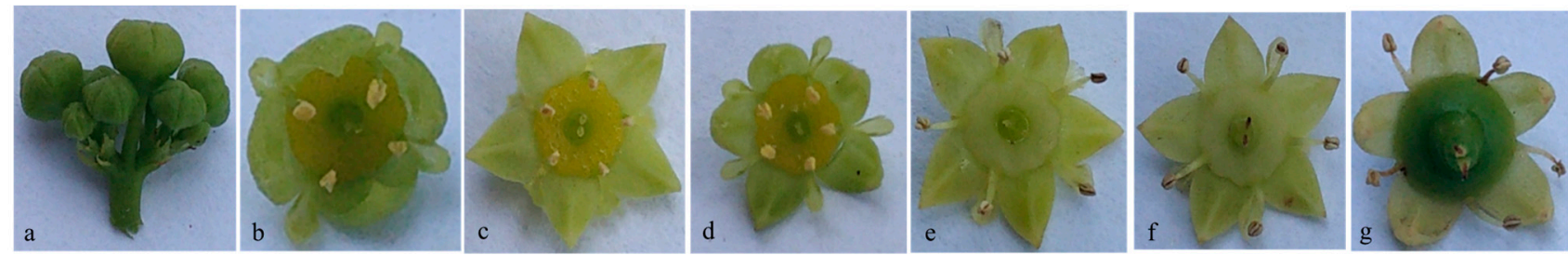

Figure 1. Flower development stages of 'Maya' jujube. (a): bud split; (b): initial opening; (c): sepal flattening; (d): petal flattening; (e): stamen flattening; (f): stamen withering, (g): ovary swelling.

The morphological characteristics of chromosomes at different meiotic stages of male gamete development were observed (Figure 2). In prophase I leptotene (Figure 2a), zygotene (Figure 2b), pachytene (Figure 2c), diplotene (Figure 2d), and diakinesis (Figure 2e) were observed. Many chromosomal changes, such as a disorderly chromosome arrangement, gradual contraction, and intertwining of chromosomes, were observed. At metaphase $\mathrm{I}$, the chromosomes were arranged uniformly on the equatorial plate (Figure 2f). The homologous chromosomes then migrated to opposite cells poles (Figure $2 \mathrm{~g}$ ) and the nucleolus regenerated (Figure 2h). Subsequently, the cell underwent mitotic division to form a tetrad (Figure $2 \mathrm{i}-\mathrm{m}$ ). The microspores eventually developed into mature pollen grains through the mononuclear and dinuclear stages (Figure 2n-p).

The development of megaspores is shown in Figure 3. The ovary of 'Maya' jujube contains two locules (Figure 3a). Each ovule gradually developed into a functional megaspore after meiosis (Figure $3 \mathrm{~b}-\mathrm{d}$ ), which was the crucial period for induction of chromosome doubling in the female gamete. The megaspore divided to form a mononuclear embryo sac and then developed into an octonucleate mature embryo after three mitotic divisions (Figure $3 \mathrm{e}-\mathrm{k}$ ). 


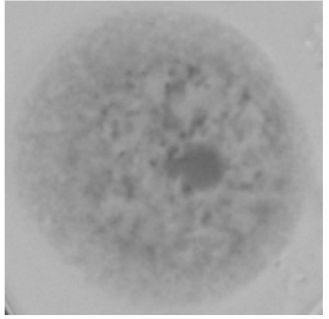

(a)

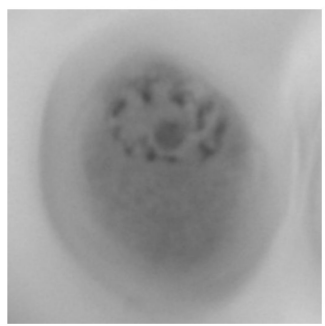

(e)

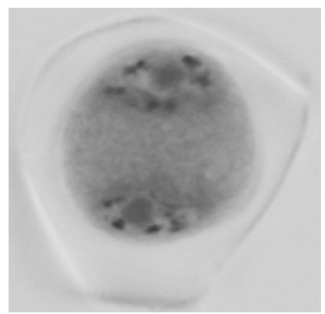

(i)

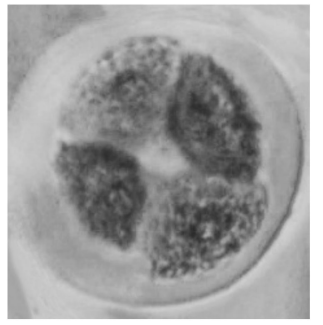

$(\mathbf{m})$

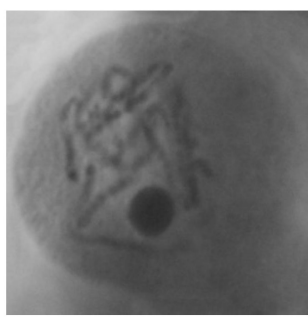

(b)

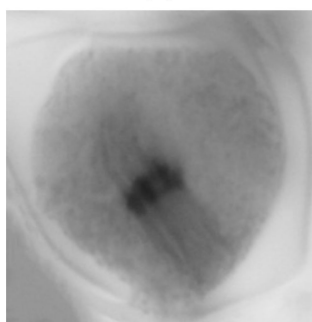

(f)

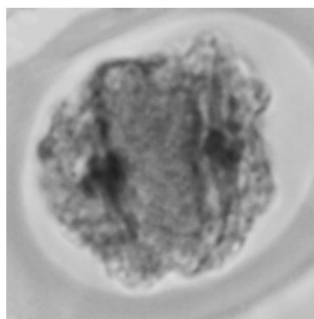

(j)

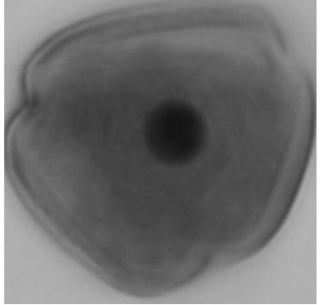

(n)

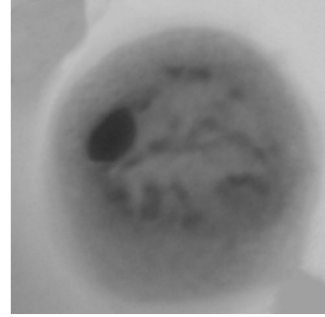

(c)

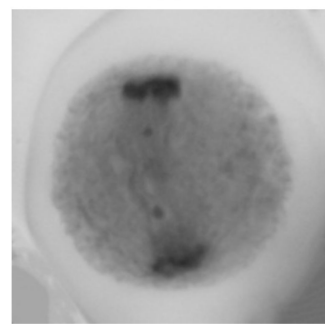

(g)

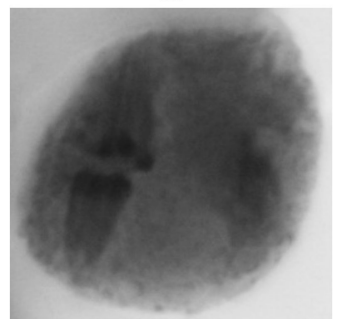

(k)

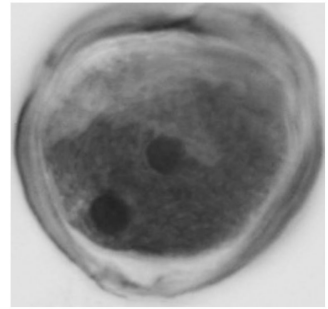

(o)

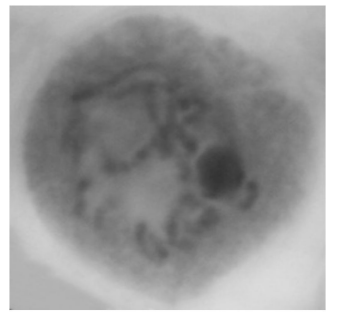

(d)

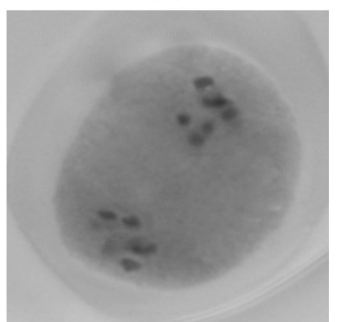

(h)

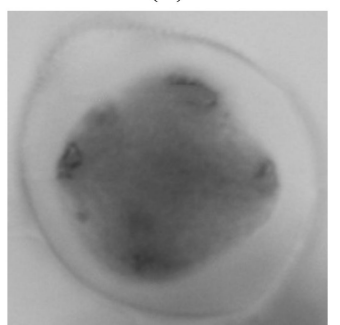

(I)

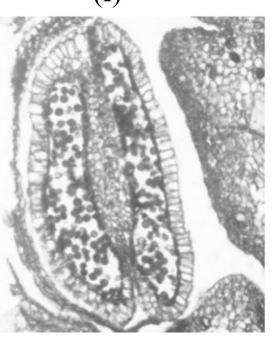

(p)

Figure 2. Microsporogenesis and development of male gametophytes (a-o scale bar $=5 \mu \mathrm{m} ; \mathbf{p}$ scale bar $=50 \mu \mathrm{m}$ ). (a) leptotene; (b) zygotene; (c) pacthytene; (d) diplotene; (e) diakinesis; (f) metaphase I; (g) anaphase I; (h) telophase I; (i) prophase II; (j) metaphase II; (k) anaphase II; (1) telophase II: (m) tetrad stage (tertrahedroid); (n) slope nucleus centered; (o) dikaryophase; (p) matured pollen grain.

\subsection{Relationship between Bud Morphology and Gametophyte Development of 'Maya' Jujube}

The temporal relationship between flower bud morphology and megaspore meiotic stage was studied to guide the optimal timing of colchicine treatment. When the diameter of the round green flower bud was $0.80-1.12 \mathrm{~mm}$, the microspore mother cell began to undergo meiosis, whereas the megaspore mother cell was undifferentiated (Figure 4 , Table 3). When the flower bud diameter was $1.13-1.20 \mathrm{~mm}$, the microspore mother cells were at the leptotene to diakinesis stages, whereas the megaspore mother cells remained undifferentiated. When the flower buds were dark green and 1.21-1.33 mm in diameter, the microspore mother cells underwent meiosis to telophase I, and megaspore mother cells remained undifferentiated. At floral bud diameters of 1.34-1.38 mm, the microspore mother cells were at prophase II to telophase II and an archespore differentiated from a nucellus cell. At the floral bud, diameters of $1.76-2.12 \mathrm{~mm}$, the bud color was initially dark green and gradually changed to light green as the bud diameter increased; at this stage the megaspore mother cell underwent meiosis, followed by development of the 
female gametophyte. Thus, meiosis of the megaspore mother cell occurred at flower bud diameters of 1.76-2.12 mm, which was the appropriate stage to induce the formation of $2 n$ female gametes. At this stage, colchicine treatment could induce megaspore chromosome doubling and obtain polyploidy.

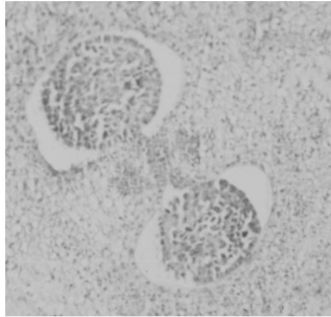

(a)

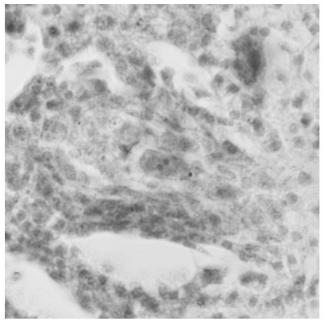

(e)

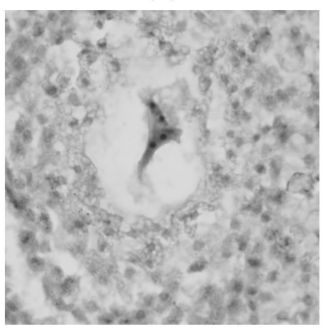

(i)

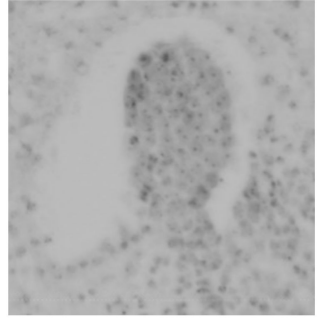

(b)

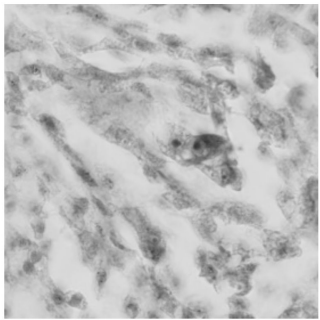

(f)

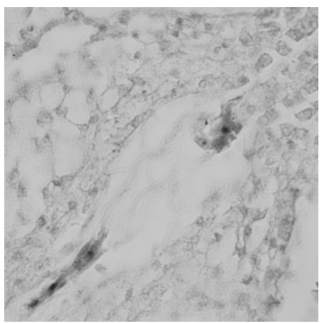

(j)

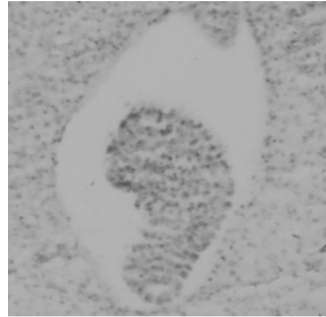

(c)

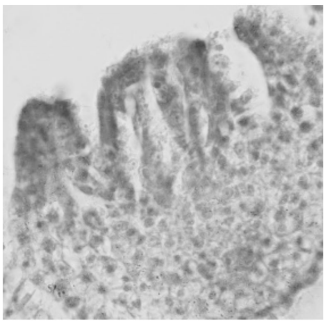

(g)

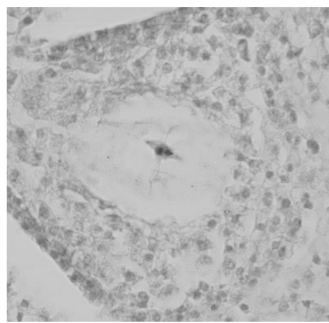

$(\mathbf{k})$

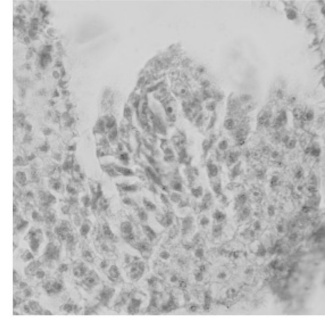

(d)

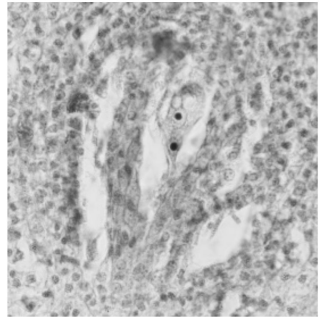

(h)

Figure 3. Megasporogenesis and the development of female gametophyte (a-k scale bar $=20 \mu \mathrm{m})$. (a) Longitudinal section of flower bud; (b) ovule primordia; (c) new formed ovule primordial; (d) megaspore mother cell; (e) dyad period; (f) tetrad stage; (g) mononuclear embryo; (h) two-nucleate embryo; (i) tetranuclear embryo; (j,k) octonucleate embryo.

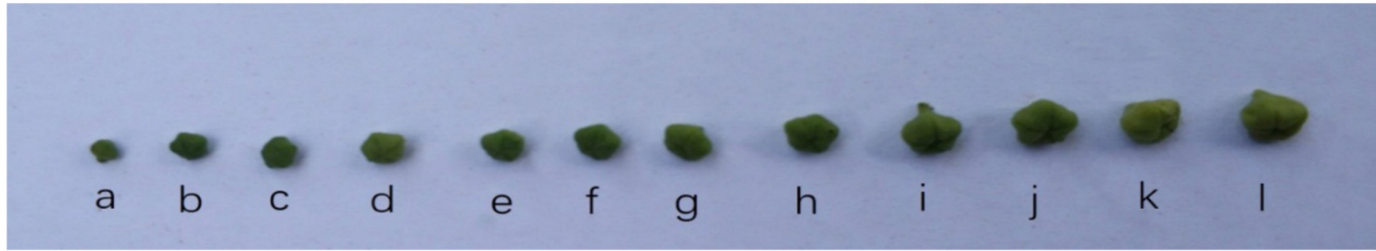

Figure 4. Morphological characteristics of different flower size of 'Maya' jujube.

\subsection{Water Transport of 'Maya' Jujube Shoots}

The water transport rate of 'Maya' jujube shoots was studied to guide colchicine treatment. After the dye was introduced into the stems, the rate of solution transport in lignified and semi-lignified shoots was fastest within the first hour (Figure 5). The transport distance of the dye exceeded $10 \mathrm{~cm}$ at $30 \mathrm{~min}$ after treatment. The average transport rate of the dye solution was more than $10 \mathrm{~cm} / \mathrm{h}$ and the transport distance approached $50 \mathrm{~cm}$ within $3 \mathrm{~h}$. The shoot tips and the entire leaves, including the veins and lamina, were stained red at $3 \mathrm{~h}$ and $40 \mathrm{~min}$ (Figure 6). These results indicated that the treated shoots were capable of fully absorbing colchicine solution at $\sim 4 \mathrm{~h}$ in a field experiment. 
Table 3. The relationships between flower morphological characteristics and the male and female gametophytes development stages in 'Maya' Jujube.

\begin{tabular}{|c|c|c|c|c|}
\hline $\begin{array}{l}\text { External } \\
\text { Morphology } \\
\text { of Bud }\end{array}$ & $\begin{array}{l}\text { Bud Diameter } \\
(\mathrm{mm})\end{array}$ & Bud Form & $\begin{array}{c}\text { Microspore Mother Cell } \\
\text { Development }\end{array}$ & $\begin{array}{l}\text { Megaspore Mother } \\
\text { Cell Development }\end{array}$ \\
\hline $\mathrm{a}$ & $0.80-1.12$ & Slightly raised, green & $\begin{array}{l}\text { Archespore, microspore } \\
\text { mother cell }\end{array}$ & Undifferentiated \\
\hline $\mathrm{b}$ & $1.13-1.20$ & Slightly enlarged, green & Leptotene-diakinesis & Undifferentiated \\
\hline c & $1.21-1.33$ & Continue to swell, green & Metaphase I-telophase I & Undifferentiated \\
\hline $\mathrm{d}$ & $1.34-1.38$ & Continue to swell, light green & Prophase II-telophase II & Archespore \\
\hline e & $1.39-1.56$ & Continue to swell, light green & $\begin{array}{l}\text { tetrad stage-slope } \\
\text { nucleus centered }\end{array}$ & $\begin{array}{l}\text { Archespore- } \\
\text { sporogenous }\end{array}$ \\
\hline $\mathrm{f}$ & $1.57-1.75$ & Sepals distinct, pale green & $\begin{array}{l}\text { slope nucleus } \\
\text { centered-mononuclear } \\
\text { fringe phase }\end{array}$ & Sporogenous \\
\hline $\mathrm{g}$ & $1.76-2.12$ & Sepals distinct, yellowish green & $\begin{array}{l}\text { mononuclear fringe } \\
\text { phase-dikaryophase }\end{array}$ & Megaspore mother cell \\
\hline $\mathrm{h} \sim \mathrm{i}$ & $2.13-2.50$ & Sepals distinct, yellowish green & Dikaryophase & $\begin{array}{l}\text { Dyad-function } \\
\text { macrospore }\end{array}$ \\
\hline $\mathrm{j}$ & $2.51-2.90$ & Sepals about to crack, yellow & Mature pollen grain & $\begin{array}{c}\text { Mononuclear embryo } \\
\text { Sac-tetruclear } \\
\text { embryo sac }\end{array}$ \\
\hline $\mathrm{k} \sim 1$ & $>2.90$ & Sepals about to crack, yellow & Mature pollen grain & Ockaryotic embryo sac \\
\hline
\end{tabular}

Note: The external morphology of the bud in the table corresponds to the development of the bud in Figure 4.

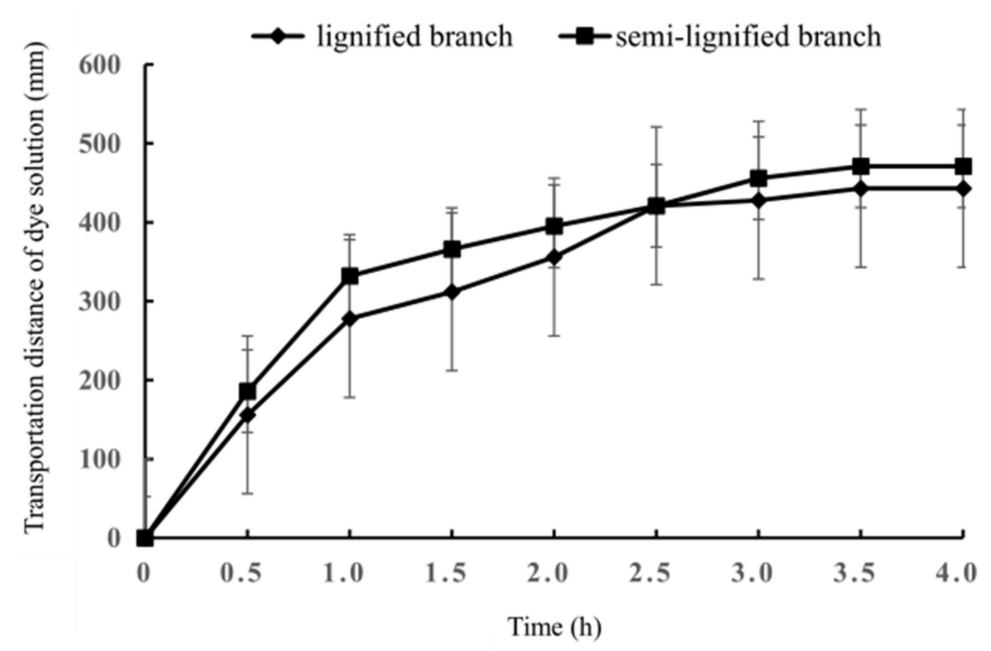

Figure 5. Transport rate of dye solution.

\subsection{Colchicine-Induced Chromosome Doubling of Female Gametes of 'Maya' Jujube}

After colchicine treatment using two methods (improved cotton leaching and injection method) and three concentrations $(0.3 \%, 0.4 \%$, and $0.5 \%)$, a total of 1037 bearing shoots survived. Excluding the withered and yellowed bearing shoots treated with $0.5 \%$ colchicine solution, the other treated shoots developed normally (Table 4). This observation indicated that $0.5 \%$ colchicine was excessive, and might have had a toxic effect on the treated bearing shoots. The number of surviving shoots after treatment ranged from 151 to 196. The highest number of surviving shoots was observed in treatment was $5(0.4 \%$ colchicine, improved cotton leaching) and the fewest were observed in treatment was 2 ( $0.4 \%$ colchicine, injection method). 

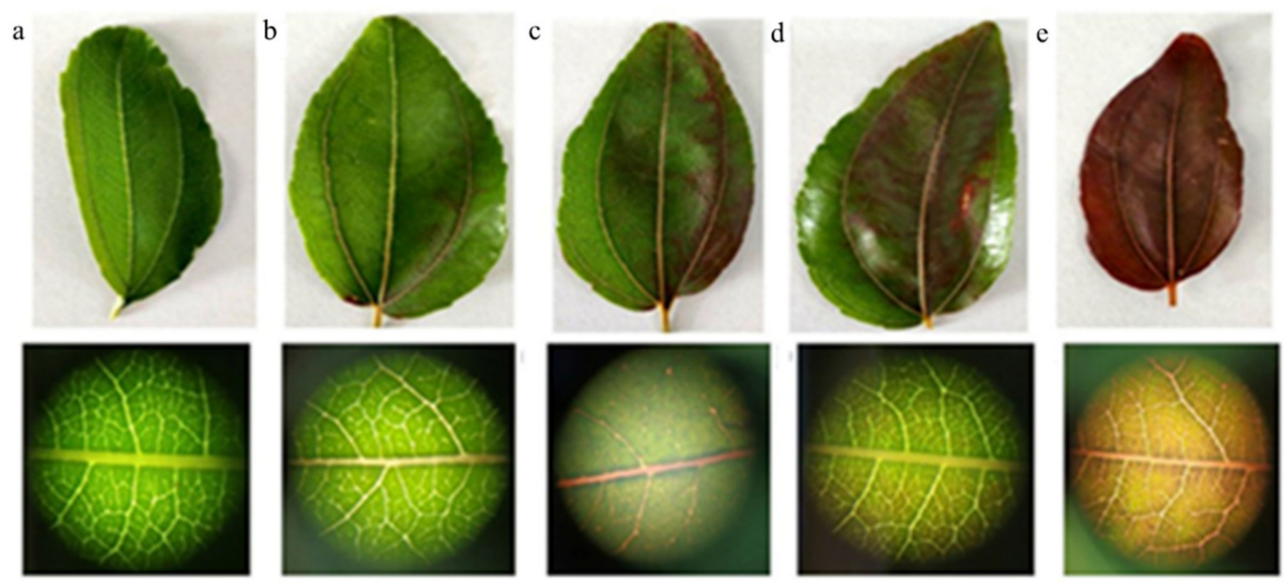

Figure 6. Distribution of dye in veins and lamina after different treatment time. (a) Untreated leaf; (b) $3 \mathrm{~h} \mathrm{and} 10 \mathrm{~min}$; (c) $3 \mathrm{~h}$ and $20 \mathrm{~min}$; (d) $3 \mathrm{~h}$ and $30 \mathrm{~min}$; (e) $3 \mathrm{~h}$ and $40 \mathrm{~min}$.

In September, a total of 616 seeds were collected from the treated shoots. A total of 358 seeds (58.1\%) germinated in December. After 30 days, 286 seedlings were obtained (percentage seedling survival 46.4\%) (Table 4).

\subsection{Ploidy Determination and Paternal Analysis}

The ploidy of all progenies was detected by flow cytometry. Two triploid seedlings were identified (Figure 7). The triploid individuals were among the progeny of flower buds treated with a $0.3 \%$ colchicine solution using the improved cotton leaching method (triploid yield 3.3\%) (Table 4).
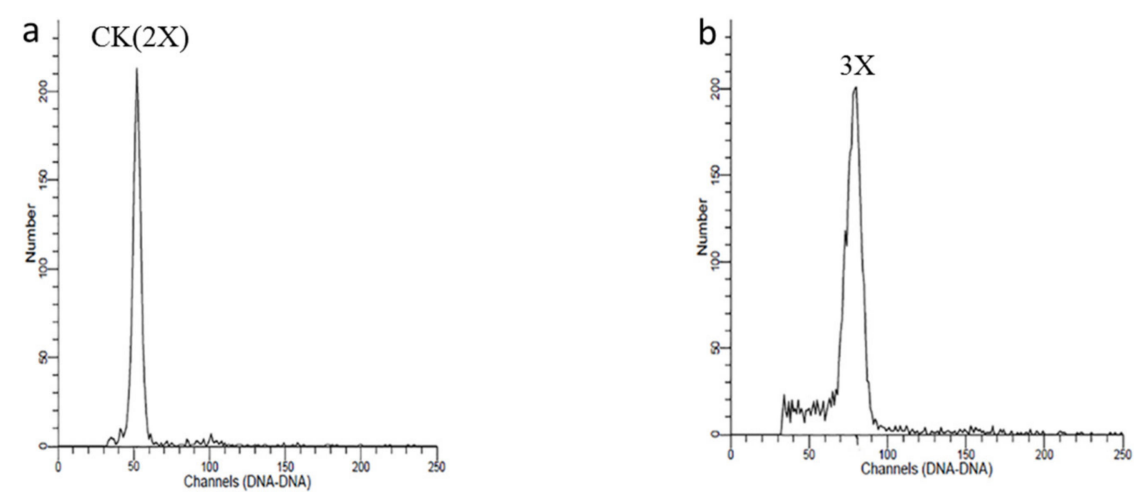

Figure 7. Ploidy level detection of offspring by flow cytometry. (a) CK represent untreated diploid offspring $(2 n=2 x=24) ;(\mathbf{b})$ triploid offspring $(2 n=3 x=36)$.

Analysis with simple sequence repeat (SSR) markers demonstrated that the male parent of the triploid germplasm was sour jujube, and four diploid offspring shared the same parents (Table 5). By comparing the allelic configuration corresponding to the marker sites of the same primers for the triploid offspring with that of the parent, it was shown that two chromosomes were derived from the maternal parent and one chromosome from the paternal parent. These results confirmed that the triploid seedlings were derived from megaspores that had undergone chromosome doubling (Figure 8). 
Table 4. The experiment treatment and results of colchicine inducing triploid of 'Maya' jujube.

\begin{tabular}{|c|c|c|c|c|c|c|c|c|c|c|c|}
\hline Treatment & $\begin{array}{l}\text { Number of } \\
\text { Treated } \\
\text { Shoots }\end{array}$ & $\begin{array}{l}\text { Number of } \\
\text { Treated } \\
\text { Bearing } \\
\text { Shoots }\end{array}$ & $\begin{array}{l}\text { Number of } \\
\text { Survived } \\
\text { Bearing } \\
\text { Shoots }\end{array}$ & $\begin{array}{c}\text { External } \\
\text { Morphology of Bearing } \\
\text { Shoots }\end{array}$ & $\begin{array}{l}\text { Number of } \\
\text { Treated } \\
\text { Seeds }\end{array}$ & $\begin{array}{l}\text { Number of } \\
\text { Germinated } \\
\text { Seeds }\end{array}$ & $\begin{array}{c}\text { Germination } \\
\text { Rate }(\%)\end{array}$ & $\begin{array}{l}\text { Seedling } \\
\text { Number }\end{array}$ & $\begin{array}{l}\text { Seedling } \\
\text { Survival } \\
\text { Rate (\%) }\end{array}$ & $\begin{array}{l}\text { Triploid } \\
\text { Number }\end{array}$ & $\begin{array}{l}\text { Triploid } \\
\text { Rate (\%) }\end{array}$ \\
\hline 1 & 6 & 164 & 160 & Normal growth & 107 & 67 & 62.6 & 42 & 39.3 & 0 & 0 \\
\hline 2 & 6 & 151 & 151 & Normal growth & 108 & 60 & 55.6 & 53 & 49.1 & 0 & 0 \\
\hline 3 & 6 & 172 & 167 & Some appear wilted and yellow & 95 & 52 & 54.7 & 44 & 46.3 & 0 & 0 \\
\hline 4 & 6 & 183 & 183 & Normal growth & 126 & 72 & 57.1 & 61 & 48.4 & 2 & 3.3 \\
\hline 5 & 6 & 196 & 196 & Normal growth & 92 & 57 & 62.0 & 49 & 53.3 & 0 & 0 \\
\hline 6 & 6 & 185 & 180 & Some appear wilted and yellow & 88 & 50 & 56.8 & 37 & 42.0 & 0 & 0 \\
\hline Total & 36 & 1051 & 1037 & & 616 & 358 & 58.1 & 286 & 46.4 & 2 & 3.3 \\
\hline
\end{tabular}


Table 5. Paternal identification results.

\begin{tabular}{cccc}
\hline Offspring Name & Mother Name & Pair LOD Score & Candidate Father \\
\hline TM & Maya jujube & 7.73 & Sour jujube \\
DM-6-10 & Maya jujube & 6.46 & Datian Sour jujube \\
DM-6-11 & Maya jujube & 6.34 & Dabai jujube \\
DM-6-12 & Maya jujube & 7.52 & Sour jujube \\
DM-6-14 & Maya jujube & 6.54 & Sour jujube \\
DM-6-15 & Maya jujube & 3.80 & Datian Sour jujube \\
DM-6-17 & Maya jujube & 4.75 & Sour jujube \\
DM-6-18 & Maya jujube & 7.84 & Xiaobai jujube \\
DM-6-19 & Maya jujube & 5.32 & Datian Sour jujube \\
DM-6-20 & Maya jujube & 7.84 & Xiaobai jujube \\
DM-6-21 & Maya jujube & 7.25 & Datian Sour jujube \\
DM-7-1 & Maya jujube & 7.84 & Dabai jujube \\
DM-7-2 & Maya jujube & 7.20 & Dabai jujube \\
DM-7-3 & Maya jujube & 7.84 & Dabai jujube \\
DM-7-4 & Maya jujube & 4.74 & Sour jujube \\
DM-7-5 & Maya jujube & 6.06 & Sour jujube \\
\hline
\end{tabular}
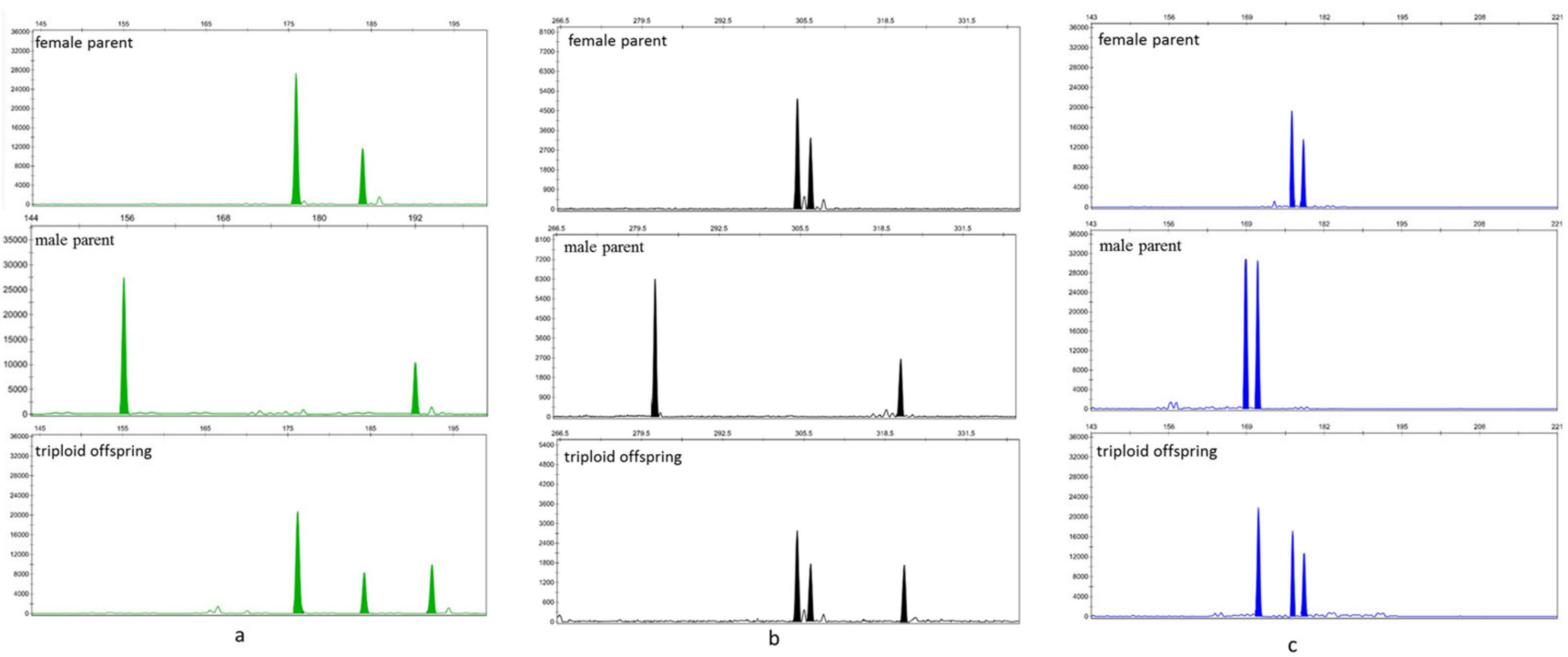

Figure 8. Allele configurations of three pairs of primers in triploid hybrids. (a) BFU 0308; (b) BFU 0377; (c) BFU 1205. Each row represents the female parent, male parent, and triploid offspring, respectively.

\subsection{Phenotypic Trait Assessment of Triploid and Diploid Offspring}

The phenotypic traits of a triploid plant (TM) and three diploid plants (DM-6-14, DM7-4, and DM-7-5) derived from the same parents were compared. Although the height of the triploid plant was significantly less than that of the diploid plants, the ground diameter, thorn length, leaf width, leaf area and chlorophyll content were significantly higher than those of the diploid plants (Table 6, Figure 9). Additionally, measurement of photosynthetic parameters indicated that the triploid plant showed higher photosynthetic efficiency than that of the diploid plants. The photosynthetic rate $(P n)$, stomatal conductance $(G s)$, transpiration rate $(\mathrm{Tr})$, and photosynthetic efficiency of a whole leaf (PEw) of the triploid plants were significantly higher than those of the diploid plants based on one-way ANOVA F-tests (Table 7). 
Table 6. Comparison of phenotypic traits between diploid and triploid plants.

\begin{tabular}{|c|c|c|c|c|c|c|c|}
\hline Ploidy & Height (cm) & $\begin{array}{c}\text { Ground } \\
\text { Diameter } \\
(\mathrm{mm})\end{array}$ & $\begin{array}{c}\text { Thorn } \\
\text { Length }(\mathrm{mm})\end{array}$ & $\begin{array}{l}\text { Leaf Length } \\
\text { (cm) }\end{array}$ & $\begin{array}{l}\text { Leaf Width } \\
\quad(\mathrm{cm})\end{array}$ & $\begin{array}{l}\text { Leaf Area } \\
\qquad\left(\mathrm{cm}^{2}\right)\end{array}$ & $\begin{array}{c}\text { Chlorophyll } \\
\text { Content }\end{array}$ \\
\hline DM-6-14 & $40.33 \pm 1.15 b$ & $4.37 \pm 0.12 b$ & $3.75 \pm 0.27 b c$ & $3.41 \pm 0.35 c$ & $1.29 \pm 0.22 c$ & $3.84 \pm 0.53 c$ & $34.58 \pm 4.64 b$ \\
\hline DM-7-4 & $42.67 \pm 1.52 \mathrm{ab}$ & $4.40 \pm 0.10 \mathrm{~b}$ & $8.23 \pm 0.23 b$ & $4.36 \pm 0.56 a$ & $1.81 \pm 0.20 \mathrm{~b}$ & $5.42 \pm 1.74 b$ & $32.77 \pm 3.99 b$ \\
\hline DM-7-5 & $43.33 \pm 1.15 a$ & $4.43 \pm 0.12 b$ & $4.55 \pm 0.13 c$ & $3.84 \pm 0.48 b$ & $1.77 \pm 0.24 b$ & $3.99 \pm 0.90 c$ & $35.11 \pm 2.89 b$ \\
\hline TM & $29.22 \pm 1.53 c$ & $5.06 \pm 0.057 a$ & $9.35 \pm 0.14 a$ & $4.19 \pm 0.42 \mathrm{ab}$ & $2.26 \pm 0.32 \mathrm{a}$ & $6.73 \pm 1.18 \mathrm{a}$ & $39.46 \pm 6.36 a$ \\
\hline
\end{tabular}

Note: The data in the table represent 30 repeated mean \pm SD by two-sample test $(p<0.05)$. Different letters in the same column indicate significant differences between the two ploidy plants.
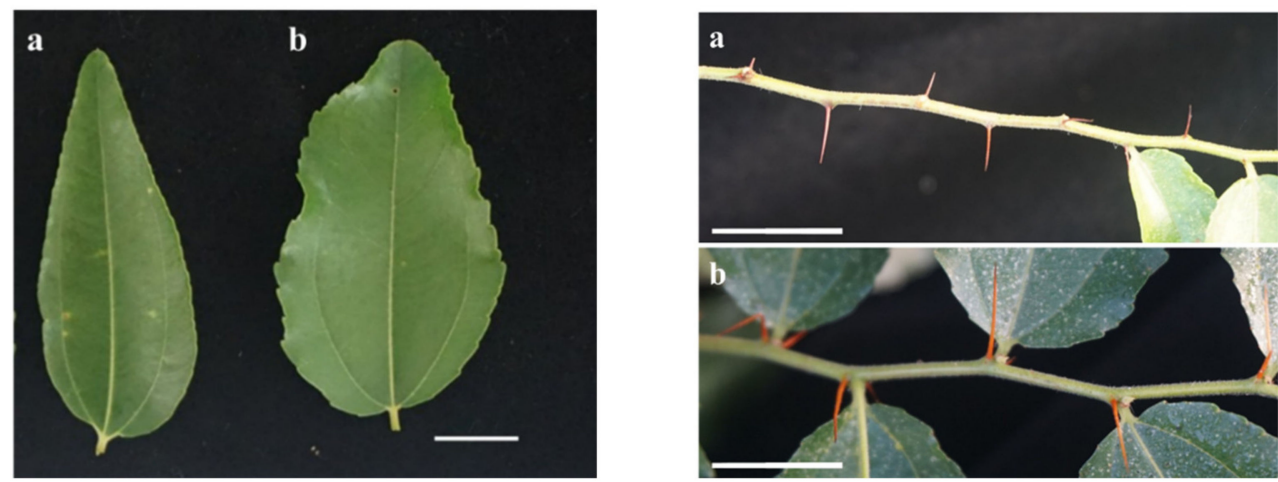

Figure 9. The leaves and thorns of diploid and triploid plants. (a) Diploid, (b) triploid; scale bar $=1 \mathrm{~cm}$.

Table 7. Comparison of photosynthetic characters between diploid and triploid plants.

\begin{tabular}{|c|c|c|c|c|c|c|}
\hline Ploidy. & $\frac{\text { Pn }}{\left(\mu \mathrm{mol} \cdot \mathrm{m}^{-2} \cdot \mathrm{s}^{-1}\right)}$ & $\begin{array}{c}\mathrm{Gs} \\
\left(\mathrm{mol} \cdot \mathrm{m}^{-2} \cdot \mathrm{s}^{-1}\right)\end{array}$ & $\underset{\left(\mu \mathrm{mol} \cdot \mathrm{m}^{-1}\right)}{\mathrm{Ci}}$ & $\underset{\left(\mathrm{mmol} \cdot \mathrm{m}^{-2} \cdot \mathrm{s}^{-1}\right)}{\operatorname{Tr}}$ & WUEi & $\begin{array}{c}\text { PEw } \\
\left(\mu \mathrm{mol} \cdot \mathrm{s}^{-1}\right)\end{array}$ \\
\hline DM-6-14 & $6.163 \pm 0.24 b$ & $0.161 \pm 0.017 \mathrm{~b}$ & $233.1 \pm 46.26 \mathrm{ab}$ & $4.043 \pm 0.11 b$ & $1.526 \pm 0.088 \mathrm{ab}$ & $0.00237 \pm 0.0081 b$ \\
\hline DM-7-4 & $4.873 \pm 0.48 c$ & $0.093 \pm 0.54 b$ & $188.8 \pm 7.80 \mathrm{c}$ & $2.967 \pm 0.34 c$ & $1.679 \pm 0.45 \mathrm{ab}$ & $0.00264 \pm 0.0082 b$ \\
\hline DM-7-5 & $5.236 \pm 0.38 c$ & $0.168 \pm 0.069 b$ & $228.4 \pm 16.3 \mathrm{ab}$ & $4.123 \pm 0.10 b$ & $1.269 \pm 0.082 c$ & $0.00209 \pm 0.0091 b$ \\
\hline TM & $9.583 \pm 0.24 a$ & $0.270 \pm 0.62 \mathrm{a}$ & $279.7 \pm 9.69 a$ & $4.837 \pm 0.17 a$ & $1.982 \pm 0.022 \mathrm{a}$ & $0.00645 \pm 0.0062 \mathrm{a}$ \\
\hline
\end{tabular}

Note: The data in the table represent 30 repeated mean \pm SD by two-sample test $(p<0.05)$. Different letters in the same column indicate significant differences between the two ploidy plants. Pn: photosynthetic rate; Gs: stomatal conductance; Ci: intercellular carbon dioxide concentration; Tr: transpiration rate; WUEi: instantaneous water use efficiency; PEw: photosynthetic efficiency of a whole leaf.

The stomatal length and width of the triploid plant were approximately 4.37 and 1.54 times higher, respectively, than those of the diploid plants. However, the stomatal density was significantly lower than that of the diploid plants (Table 8, Figure 10).

Table 8. Stomatal characters of diploid and triploid plants.

\begin{tabular}{cccc}
\hline Ploidy & Stomata Height $(\boldsymbol{\mu m})$ & Stomata Width $(\boldsymbol{\mu m})$ & Stomata Density $\left(\mathbf{N o} . \mathbf{m m}^{\mathbf{2}}\right)$ \\
\hline DM-6-14 & $18.78 \pm 0.73 \mathrm{~b}$ & $16.00 \pm 0.52 \mathrm{~b}$ & $465.88 \pm 17.07 \mathrm{a}$ \\
DM-7-4 & $17.29 \pm 0.20 \mathrm{c}$ & $16.37 \pm 0.61 \mathrm{~b}$ & $474.23 \pm 22.05 \mathrm{a}$ \\
DM-7-5 & $17.84 \pm 0.55 \mathrm{bc}$ & $15.83 \pm 0.68 \mathrm{~b}$ & $460.71 \pm 26.79 \mathrm{a}$ \\
TM & $22.34 \pm 0.52 \mathrm{a}$ & $17.61 \pm 0.41 \mathrm{a}$ & $356.25 \pm 23.51 \mathrm{~b}$ \\
\hline
\end{tabular}

Note: The data in the table represent 30 repeated mean \pm SD by two-sample test $(p<0.05)$. Different letters in the same column indicate significant differences between the two ploidy plants. 

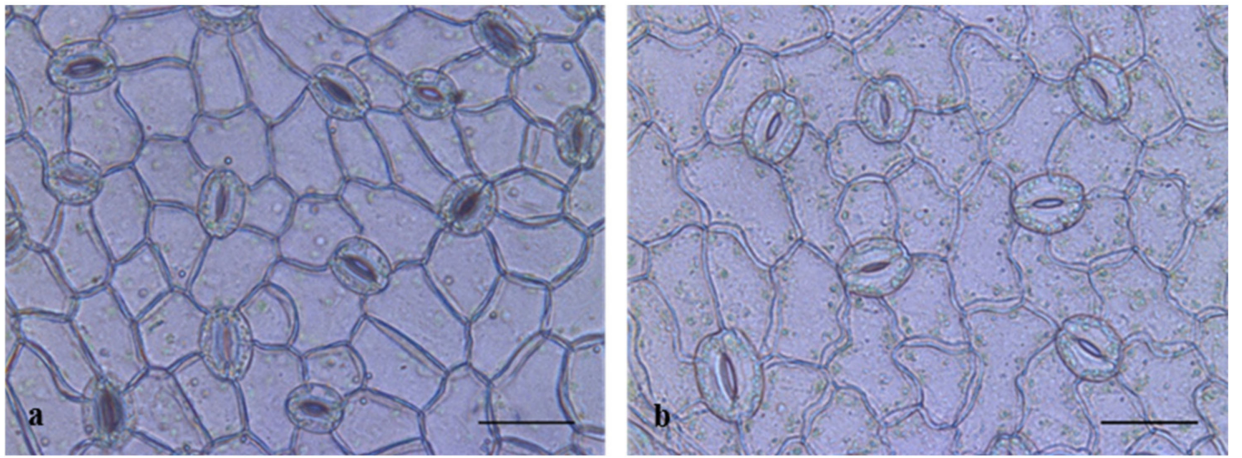

Figure 10. Stomatal characters of diploid and triploid plants. (a) Diploid, (b) triploid; scale bar $=20 \mu \mathrm{m}$.

\section{Discussion}

The efficiency of $2 n$ gamete induction depends on the suitability of the treatment period for chromosome doubling $[8,19]$. Previous studies on poplar demonstrated that the optimal meiotic stages for colchicine treatment to induce chromosome doubling of megaspores are leptotene-pachytene [12,32]. The leptotene-diakinesis stages of meiosis in the flower buds might be the optimal period for megaspore and microspore chromosome doubling by colchicine treatment in Eucalyptus urophylla [8,14]. However, the megaspore mother cell is enclosed in the ovule, therefore, the development of the megaspore mother cell can only be observed using thin-section technology [9,33]. The process of generating thin sections is time-consuming, thus, it is difficult to observe and determine the meiosis stage immediately. By establishing the temporal relationship between flower-bud morphogenesis and female meiotic stages, the process of meiosis can be tracked based on flower-bud morphology and the optimal treatment period for chromosome doubling of megaspores can be determined [18,34]. Li et al. [35] established the relationship between flower-bud morphogenesis and female meiotic stages in Eucommia. Catkins were treated in which one-third of the flower buds protruded beyond the bract scales; the proportion of triploids obtained among the offspring was $51.43 \%$. The relationship between megasporogenesis and the external morphology of male and female flower buds was established to guide colchicine treatment of rubber; the efficiency of triploid induction was approximately 9.1\% [19]. In the present study, we established the relationship between flower-bud morphogenesis and megaspore development in 'Maya' jujube. When the flower bud diameter was $1.76-2.12 \mathrm{~mm}$, the megaspore mother cell enters the optimal stage of meiosis for megaspore chromosome doubling. This result is similar, but not entirely comparable to the flower bud diameter in research on $2 n$ female gamete induction in 'Dongzao' jujube [36]. The most likely reason for the difference is that the period of megasporogenesis is inconsistent among cultivars of jujube.

Plant species vary in response to colchicine treatment for induction of chromosome doubling of male and female gametes. The optimal colchicine concentration of induction for $2 n$ pollen in poplar is $0.5 \%-0.8 \%[12,37,38]$. A similar result was reported for Eucalyptus [14] A high frequency of $2 n$ pollen induction can be achieved by injecting $0.6 \%$ colchicine into flower buds four times within $2 \mathrm{~h}$ interval in Populus $\times$ popularis [39]. Injection of flower buds with $0.8 \%$ colchicine resulted in a $2 n$ pollen induction frequency of $87.11 \%$ in black poplar [40]. However, the optimal colchicine concentration for induction of $2 n$ female gametes is lower. Li et al. [7] treated female buds of Populus alba $\times$ P. glandulosa with $0.5 \%$ colchicine solution at selected meiotic stages to obtain 12 triploids. The concentration of colchicine that induces chromosome doubling of female gametes varies among tree species; for example, $0.3 \%$ in cassava [13] and $0.25 \%$ in Eucalyptus [8]. In the present study, colchicine concentrations of $0.3 \%, 0.4 \%$, and $0.5 \%$ were used to induce megaspore chromosome doubling of flower buds. The optimal concentration was $0.3 \%$ and triploid plants were successfully obtained. Given that $0.3 \%$ was the lowest colchicine concentration used in our study, the inductive effect of lower concentrations is unknown and should be investigated in a future study. 
When colchicine is used as a mutagen, to improve the efficiency of chromosome doubling, it is important to choose an appropriate treatment method in accordance with the characteristics of the research material. The reported methods of colchicine treatment include immersion, injection, cotton leaching, and coating [7,41,42]. For branches inserted in water in a greenhouse, an immersion or injection method is often used for induction of gamete chromosome doubling [37,38]. Li et al. [7] and Wang et al. [41] used the immersion method to successfully induce $2 n$ female gametes in poplar. Liu et al. [43] and Zhou et al. [44] successfully obtained $2 n$ pollen with the injection method when exploring the effects of colchicine on gamete chromosome doubling in poplar. However, for plant materials to which colchicine solution can only be applied to a tree in vivo to induce gamete chromosome doubling, injection and cotton leaching are the preferred methods. Yang et al. [14] injected colchicine solution into flower buds and successfully induced $2 n$ pollen of Eucalyptus with a frequency of $28.71 \%$. The same method was used to induce $2 n$ female gametes of Eucalyptus and triploids were successfully obtained with efficiency of $6.25 \%$ [8]. Cotton leaching was used to treat flower buds of cassava for induction of $2 n$ gametes and two sexual tetraploid plants were obtained [13]. For jujube, given the small flower size and large number of flowers produced, it is extremely difficult to directly inject colchicine solution into the flower buds. The improved cotton leaching method used in the present study enabled the introduction of the colchicine solution into the secondary shoot, and its transport to the flower bud through the xylem, thereby inducing chromosome doubling of female gametes. Compared with the standard cotton leaching method [12], the present method introduces colchicine solution into the shoot, enabling simultaneous treatment of a large number of flower buds, and the incision into the secondary shoot extends to the xylem, which is conducive to the transport of colchicine in the vascular tissue. The improved cotton leaching method is more suitable for treatment of tree species that produce small flowers or profusion of flowers. Among the two treatment methods used in the current study, the improved cotton leaching method was more effective and successfully resulted in triploid plants.

Chromosome doubling usually leads to changes in morphology, physiology, and gene expression patterns in many species [45-47]. Polyploid plants typically show superiority in vegetative growth in comparison with control plants $[48,49]$. The height growth and diameter growth of natural triploid wild cherries are superior to those of diploid plants [50]. The leaf area of triploid poplar plants is significantly larger than that of their full-sibling diploid plants [47]. In the present study, the ground diameter, leaf width, and leaf area of triploid plants were significantly higher than those of diploid plants, which was consistent with the findings of the majority of comparative studies of diploid and triploid plants [49-51]. The most direct cell-level manifestation of polyploidy is an increase in cell volume. Cell-size enlargement plays a pivotal role in the increase in leaf size of triploid poplar [47]. In many plant species, ploidy is positively correlated with stomatal length and width, and is negatively correlated with stomatal density [52-54]. In the present study, the stomatal length and width of triploid germplasm were 4.37 and 1.54 times that of the average of diploid plants, whereas the stomatal density was significantly lower than that of diploid plants, which was consistent with stomata characteristics of many polyploid plants. Triploid plants may show increased photosynthetic efficiency as a result of increase in leaf area and chlorophyll content $[49,55,56]$. The leaf area, chlorophyll content, and photosynthetic rate of triploid plants are significantly higher than those of diploid plants in poplar [49], Eucalyptus [8], Eucommia [32], and citrus [2]. Compared with diploid plants, triploid plants showed a higher chlorophyll content and photosynthetic rate in the present study. These results indicated that the hybrid triploid plants possessed traits beneficial for vegetative growth in contrast to diploid plants.

\section{Conclusions}

This study proved that induction of $2 n$ megaspores is an effective approach to produce triploid jujube artificially. The optimal treatment stage of megaspore mother cell enters 
the meiosis for chromosome doubling can be induced from flower-bud morphogenesis. The improved cotton leaching are effective method for triploid induction by colchicine treatment during megasporogenesis. Hybrid triploid plants possessed traits beneficial for vegetative growth in contrast to diploid plants. Our study provided an effective way for jujube triploid breeding and it can be expected to promote and accelerate triploid breeding in fruit trees.

Author Contributions: Conceptualization: Y.L., X.L., and S.L.; formal analysis: S.L., C.Z., and L.H.; investigation: M.L., W.Y., and S.L.; methodology: S.L. and X.L.; supervision: Y.L. and X.P.; writing: S.L. and Y.L. All authors have read and agreed to the published version of the manuscript.

Funding: This research was financially supported by The National Key Research and Development Program of China (2018YFD1000607) and The Fundamental Research Funds for the Central Universities (no. 2016ZCQ05).

Institutional Review Board Statement: Not applicable.

Informed Consent Statement: Not applicable.

Data Availability Statement: The data presented in this study are available in article.

Conflicts of Interest: The authors declare that they have no conflict of interest. The experiments were performed in accordance with all relevant Chinese laws.

\section{References}

1. Wang, L.; Luo, Z.; Wang, L.; Deng, W.; Wei, H.; Liu, P.; Liu, M. Morphological, cytological and nutritional changes of autotetraploid compared to its diploid counterpart in Chinese jujube (Ziziphus jujuba Mill.). Sci. Hortic. 2019, 249, 263-270. [CrossRef]

2. Lourkisti, R.; Froelicher, Y.; Herbette, S.; Morillon, R.; Santini, J. Triploid citrus genotypes have a better tolerance to natural chilling conditions of photosynthetic capacities and specific leaf volatile organic compounds. Front. Plant Sci. 2020, 11, 330. [CrossRef] [PubMed]

3. Pomper, K.; Lowe, J.; Crabtree, S.; Vincent, J.; Raemakers, K. Ploidy level in american persimmon (Diospyros virginiana) cultivars. Hortscience 2020, 55, 4-7. [CrossRef]

4. Hias, N.; Leus, L.; Davey, M.; Stijn, V. Effect of polyploidization on morphology in two apple (Malus $\times$ domestica) genotypes. Hortic. Sci. 2017, 44, 55-63.

5. Nukaya, T.; Sudo, M.; Yahata, M.; Nakajo, Y.; Ohta, T.; Yasuda, K.; Tominaga, A.; Mukai, H.; Kunitake, H. Characteristics in autotetraploid kumquats (Fortunella spp.) induced by colchicine treatment to nucellar embryos and their utilization for triploid breeding. Sci. Hortic. 2019, 245, 210-217. [CrossRef]

6. Rao, S.; Kang, X.; Li, J.; Chen, J. Induction, identification and characterization of tetraploidy in Lycium ruthenicum. Breed. Sci. 2019, 69, 160-168. [CrossRef]

7. Li, Y.; Kang, X.; Wang, S.; Zhang, Z.; Chen, H. Triploid induction in Populus alba $\times$ P. glandulosa by chromosome doubling of female gametes. Silvae Genet. 2008, 57, 37-40. [CrossRef]

8. Yang, J.; Wang, J.; Liu, Z.; Xiong, T.; Lan, H. Megaspore Chromosome Doubling in Eucalyptus urophylla S.T. Blake induced by colchicine treatment to produce triploids. Forests 2018, 11, 728. [CrossRef]

9. Li, Y.; Wang, Y.; Wang, P.; Yang, J.; Kang, X. Induction of unreduced megaspores in Eucommia ulmoides by high temperature treatment during megasporogenesis. Euphytica 2016, 212, 515-524. [CrossRef]

10. Ulrich, K.; Ewald, D. Methods for generation of triploid aspen and poplar. Landbauforschung 2018, 68, 1-10.

11. Younis, A.; Hwang, Y.; Lim, K. Exploitation of induced 2n-gametes for plant breeding. Plant Cell Rep. 2014, 33, 215-223. [CrossRef] [PubMed]

12. Xi, X.; Guo, L.; Xu, W.; Zhang, J.; Li, B. Megasporogenesis, megagametogenesis, and induction of $2 n$ eggs with colchicine in poplar section Aigeiros. Scand. J. For. Res. 2014, 6, 527-536. [CrossRef]

13. Lai, H.; Chen, X.; Chen, Z.; Ye, J.; Li, K.; Liu, J. Induction of female $2 n$ gametes and creation of tetraploids through sexual hybridization in cassava (Manihot esculenta). Eupgytica 2015, 201, 265-273. [CrossRef]

14. Yang, J.; Yao, P.; Li, Y.; Mo, J.; Wang, J. Induction of $2 n$ pollen with colchicine during microsporogenesis in Eucalyptus. Euphytica 2016, 210, 69-78. [CrossRef]

15. Zeng, R.; Zhu, J.; Xu, S.; Du, G.; Guo, H.; Chen, J.; Zhang, Z.; Xie, L. Unreduced male gamete formation in cymbidium and its use for developing sexual polyploid cultivars. Front. Plant Sci. 2020, 11, 1-13. [CrossRef] [PubMed]

16. Wu, H.; Zheng, S.; He, Y.; Yan, G.; Bi, Y.; Zhu, Y. Diploid female gametes induced by colchicine in Oriental lilies. Sci. Hortic. 2007, 114, 50-53. [CrossRef]

17. Cheng, S.; Yang, J.; Liao, T.; Zhu, X.; Suo, Y.; Kang, X. Transcriptomic changes following synthesis of a Populus full-sib diploid and allotriploid population with different heterozygosities driven by three types of $2 n$ female gamete. Plant Mol. Biol. 2015, 89, 493-510. [CrossRef] 
18. Kang, X. Some understandings on polyploid breeding of poplars. J. Beijing For. Univ. 2010, 32, 149-153.

19. Yao, P.; Li, G.; Qiu, Y.; Kang, X. Induction of $2 n$ female gametes in rubber (Hevea brasiliensis) by high-temperature exposure during megasporogenesis as a basis for triploid breeding. Tree Genet. Genomes 2020, 16, 24. [CrossRef]

20. Geng, X.; Han, Z.; Yang, J.; Kang, X. The different origins of artificially-induced unreduced female gametes and their effect on transmitted parental heterozygosity in Populus. Euphytica 2019, 215, 181. [CrossRef]

21. Zhang, Y. Disciplines of Fruit-Set Success and Triploid Induction of Hevea brasiliensis. Master's Thesis, Beijing Forest University, Beijing, China, 2013.

22. Liu, M.; Wang, M. Chinese Jujube Germsplasm Resources, 1st ed.; China Forestry Publishing House: Beijing, China, 2009 ; pp. 39-44.

23. Chen, J.; Chan, P.; Lam, C.; Li, Z.; Lam, K.; Yao, P.; Dong, T.; Lin, H.; Lam, H.; Tsim, K. Fruit of Ziziphus jujuba (Jujube) at two stages of maturity: Distinction by metabolic profiling and biological assessment. J. Agric. Food Chem. 2015, 63, 739-744. [CrossRef] [PubMed]

24. Zhang, C.; Bian, Y.; Hou, S.; Li, X. Sugar transport played a more important role than sugar biosynthesis in fruit sugar accumulation during Chinese jujube domestication. Planta 2018, 248, 1187-1199. [CrossRef] [PubMed]

25. Wang, Z.; Liu, H. Promotion plant technology of Maya jujube. Tianjin Agric. Sci. 2008, 14, 23-24.

26. Lu, C.; He, B.; Ma, S.; Zhang, M.; Song, J.; Wei, X.; Liu, W.; Peng, R.; Li, J. Fruits microstructure characteristics of different jujube varieties during maturity. Non-Wood For. Res. 2020, 38, 119-126.

27. Wang, X.; Zhu, D.; Yang, R.; Li, X. Study on crack resistance of northern Shaanxi Jujube on mountain land. J. Fruit Sci. 2011, 28, 82-85.

28. Bondada, B.; Matthews, M.; Shackel, K. Functional xylem in the post-veraison grape berry. J. Exp. Bot. 2005, 56, 2949-2957. [CrossRef]

29. Zhao, C.; Tian, M.; Li, Y.; Zhang, P. Slow-growing pollen-tube of colchicine-induced $2 n$ pollen responsible for low triploid production rate in Populus. Euphtica 2017, 4, 94. [CrossRef]

30. Cui, Y.; Hou, L.; Li, X.; Huang, F.; Li, Y. In vitro induction of tetraploid Ziziphus jujuba Mill. var. spinose plants from leaf explants. Plant Cell Tiss. Org. 2017, 131, 175-182. [CrossRef]

31. Liang, T.; Sun, W.; Ren, H.; Ahmad, I.; Vu, N.; Marym; Huang, J. Genetic diversity of Ziziphus mauritiana germplasm based on SSR markers and ploidy level estimation. Planta 2019, 249, 1875-1887. [CrossRef]

32. Li, Y.; Yang, J.; Song, L. Study of variation in the growth, photosynthesis, and content of secondary metabolites in Eucommia triploids. Trees 2019, 33, 817-826. [CrossRef]

33. Yang, J. Reproductive Biology and Techniques of Chromosome Doubling in Eucalyptus. Ph.D. Thesis, Beijing Forest University Beijing, China, 2015.

34. Wang, J.; Li, D.; Kang, X. Induction of unreduced megaspores with high temperature during megasporogenesis in Populus. Ann. For. Sci. 2012, 69, 59-67. [CrossRef]

35. Li, D.; Tian, J.; Xue, Y.; Chen, H.; Wang, J. Triploid production via heat-induced diploidisation of megaspores in Populus pseudo-simonii. Euphytica 2019, 215, 10. [CrossRef]

36. Huang, F.; Dou, S.; Zhang, Y.; Pang, X.; Li, Y. Megasporogenesis, microsporogenesis and development of female and male gametophytes of Ziziphus jujuba Mill. Cv. Dongzao. J. Nucl. Agric. Sci. 2017, 31, 1913-1920.

37. Kang, X.; Zhu, Z.; Lin, H. Study on the effective treating period for pollen chromosome doubling of Populus tomentosa $\times$ P. bolleana. Sci. Silvae Sin. 1999, 35, 21-24.

38. Li, Y.; Guo, Q.; Wang, J.; Tian, J.; Kang, X. Colchicine-induced pollen chromosome doubling and its cytological effects in Populus alba L. J. Nucl. Agric. Sci. 2014, 28, 749-756.

39. Xi, X.; Jiang, X.; Li, D.; Guo, L.; Zhang, J.; Wei, Z.; Li, B. Induction of $2 n$ pollen by colchicine in Populus $\times$ popularis and its triploids breeding. Silvae Genet. 2011, 60, 155-160. [CrossRef]

40. Xu, W.; Zhang, Y.; Guo, L.; Zhao, J.; Zhang, J. High frequency $2 n$ pollen formation in black poplar (Populus nigra L.) induced by colchicine. Not. Bot. Horti Agrobo. 2019, 47, 939-946. [CrossRef]

41. Wang, J.; Kang, X.; Li, D.; Chen, H.; Zhang, P. Induction of diploid eggs with colchicine during embryo sac development in Populus. Silvae Genet. 2009, 59, 40-48. [CrossRef]

42. Duan, J.; Zhang, C.; Jia, M.; Zheng, M.; Cao, D.; Kang, L.; Wang, Y. Study on colchicine-induced tetraploid in Petunia hybrida Vilm. J. Shanxi Agric. Sci. 2016, 44, 951-953.

43. Liu, Y.; Zhang, Y.; Zhou, Q.; Wu, J.; Zhang, P. Colchicine did not affect the viability of induced $2 n$ pollen in Populus tomentosa. Silva Fenn. 2019, 53, 1-3. [CrossRef]

44. Zhou, Q.; Wu, J.; Sang, Y.; Zhao, Z.; Zhang, P.; Liu, M. Effects of colchicine on Populus canescens ectexine structure and $2 n$ pollen production. Front. Plant Sci. 2020, 11, 1-11. [CrossRef] [PubMed]

45. Adams, K.; Wendel, J. Polyploidy and genome evolution in plants. Curr. Opin. Plant Biol. 2005, 8, 135-141. [CrossRef] [PubMed]

46. Mu, H.; Jing, J.; Li, H.; Liu, G. Seed vigor, photosynthesis and early growth of saplings of different triploid Betula families. Dendrobiology 2012, 68, 11-20.

47. Zhang, Y.; Wang, B.; Qi, S.; Dong, M.; Wang, Z.; Li, Y.; Chen, S.; Li, B.; Zhang, J. Ploidy and hybridity effects on leaf size, cell size and related genes expression in triploids, diploids and their parents in Populus. Planta 2019, 249, 635-646. [CrossRef] [PubMed]

48. Sugiyama, S. Polyploidy and cellular mechanisms changing leaf size: Comparison of diploid and autotetraploid populations in two species of Lolium. Ann. Bot. Lond. 2005, 96, 931-938. [CrossRef] [PubMed] 
49. Liao, T.; Cheng, S.; Zhu, X.; Min, Y.; Kang, X. Effects of triploid status on growth, photosynthesis, and leaf area in Populus. Trees 2016, 30, 1137-1147. [CrossRef]

50. Warner, D.; Gerald, E. Effects of polyploidy on photosynthesis. Photosynth Res. 1993, 35, 135-147. [CrossRef]

51. Zhao, X.; Li, Y.; Mi, Z.; Bian, X.; Liu, M.; Sun, Y.; Jing, J.; Wang, F.; Li, S.; Cui, Y. Comparative analysis of growth and photosynthetic characteristics of $($ Populus simonii $\times$ P. nigra $) \times($ P. nigra $\times$ P. simonii $)$ hybrid clones of different ploidides. PLoS ONE 2015, 10, e0119259. [CrossRef]

52. Beck, S.; Dunlop, R.; Fossey, A. Stomatal length and frequency as a measure of ploidy level in black wattle, Acacia mearnsii (de Wild). Bot. J. Linn. Soc. 2003, 141, 177-181. [CrossRef]

53. Diego, P.; Amr, M.; Benedeeta, C.; Antonietta, M.G.; Valli, P.S.S.K. Ploidy levels in Citrus clementine affects leaf morphology, stomatal density and water content. Theor. Exp. Plant Phys. 2013, 25, 283-290.

54. He, P.; Li, L.; Cheng, L.; Wang, H.; Chang, Y. Variation in ploidy level and morphological traits in the progeny of the triploid apple variety Jonagold. Czech J. Genet. Plant 2018, 54, 135-142.

55. Warner, D. Effects of Polyploidy on Photosynthesis in Three C4 Plant Species. Ph.D. Thesis, Washington State University, Washington, DC, USA, 1988.

56. Wang, X.; Cheng, Z.; Zhi, S.; Xu, F. Breeding triploid plants: A review. Czech J. Genet. Plant 2016, 52, 41-54. [CrossRef] 